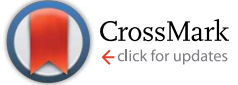

Cite this: RSC Adv., 2015, 5, 1999
Received 30th October 2014 Accepted 28th November 2014

DOI: $10.1039 / c 4 r a 14828 b$

www.rsc.org/advances

\section{Cyclotetrasiloxane frameworks for the chemoenzymatic synthesis of oligoesters $\uparrow$}

\begin{abstract}
M. B. Frampton, ${ }^{*}$ T. R. B. Jones and P. M. Zelisko*
Immobilized lipase B from Candida antarctica (Novozym ${ }^{\circledR}$ 435, N435) was utilized as part of a chemoenzymatic strategy for the synthesis of branched polyesters based on a cyclotetrasiloxane core in the absence of solvent. Nuclear magnetic resonance spectroscopy and matrix-assisted laser desorption ionization time-of-flight mass spectrometry were utilized to monitor the reactions between tetraester cyclotetrasiloxanes and aliphatic diols. The enzyme-mediated esterification reactions can achieve 65$80 \%$ consumption of starting materials in 24-48 h. Longer reaction times, $72-96 \mathrm{~h}$, resulted in the formation of cross-linked gel-like networks. Gel permeation chromatography of the polymers indicated that the masses were $M_{\mathrm{w}}=11400,13100$, and $19400 \mathrm{~g} \mathrm{~mol}^{-1}$ for the substrate pairs of $C_{7} D_{4}$ ester/ octane-1,8-diol, $C_{10} D_{4}$ ester/pentane-1,5-diol and $C_{10} D_{4}$ ester/octane-1,8-diol respectively, after $48 \mathrm{~h}$. Extending the polymerization for an additional $24 \mathrm{~h}$ with the $\mathrm{C}_{10} \mathrm{D}_{4}$ ester/octane-1,8-diol pair gave $M_{\mathrm{w}}=$ $86800 \mathrm{~g} \mathrm{~mol}^{-1}$. To the best of our knowledge this represents the first report using lipase catalysis to produce branched polymers that are built from a cyclotetrasiloxane core.
\end{abstract}

\section{Introduction}

Control over the macromolecular architecture of polymers has been advanced over the last few decades with the development of robust synthetic methodologies including atom transfer radical polymerization ${ }^{1}$ and reversible addition-fragmentation chain-transfer polymerization., ${ }^{2,3}$ The powerful nature of these techniques allows for a high degree of control over polymer architecture, the degree of polymerization, and polymer branching to be exhibited, all the while employing low catalyst loading. ${ }^{3}$

Branched (hyperbranched, dendrimeric, miktoarm, filamentous, etc.) polymers encompass a wide array of macromolecular architectures that can self-assemble into larger threedimensional architectures such as spheres, worms, and vesicles. These various architectures typically impart physical and chemical characteristics that differ from those of their linear counterparts., ${ }^{4,5}$ Hyperbranched polymers exhibit a fractal pattern of bonding and typically exhibit a greater degree of polydispersity than dendritic and linear polymers. ${ }^{6,7}$ The design of branched polymeric materials is commonly initiated from a core molecule, although this does not necessarily need to be the case ${ }^{8,9}$ Various polymers such as poly( $N$-isopropylacrylamide) $){ }^{10}$ poly(propyl ether imine) ${ }_{1}^{11}$ poly(amidoamine) ${ }^{12}$ polyethylene

Department of Chemistry and Centre for Biotechnology, Brock University, 500 Glenridge Avenue, St. Catharines, Ontario, L2S 3A1, Canada. E-mail: pzelisko@ brocku.ca; mframpton@brocku.ca; Fax: +1-905-984-4864; Tel: +1-905-688-5550 ext. 4389

$\dagger$ Electronic supplementary information (ESI) available. See DOI: $10.1039 / \mathrm{c} 4 \mathrm{ra14828b}$ glycol derivatives, ${ }^{13}$ and carbosilanes ${ }^{14}$ have been utilized as scaffolds for producing branched polymers. The potential applications of the various types of branched architectures have been examined and include drug delivery, ${ }^{14,15}$ bioconjugates, ${ }^{16}$ gene delivery, ${ }^{17}$ and self-healing coatings. ${ }^{18}$

Polysiloxane-based dendrimers/branched polymers have been known for over three decades. ${ }^{19}$ These polymers have almost exclusively possessed branched architectures of typically linear repeat units. Less common is the growth of dendrimers initiated from a functionalized cyclic siloxane core such as octamethylcyclotetrasiloxane $\left(\mathrm{D}_{4}\right)$, despite the use of $\mathrm{D}_{4}^{\mathrm{H}}$ and $\mathrm{D}_{4}^{\text {Vinyl }}$ in cross-linked silicone elastomers. Given the importance of dendrimers and other branched architectures in biomedical and related fields, it is surprising that syntheses and applications of siloxanes, which are known to be extremely biocompatible, are under described. This may be due in part to reports describing adverse effects of octamethylcyclotetrasiloxane $\left(\mathrm{D}_{4}\right)$ on the endocrine system of $\mathrm{D}_{4}$-treated mice, including an increase in the uterine wet weight and increased uterine peroxidase activity level. These observations suggested a $\mathrm{D}_{4^{-}}$ induced estrogenic activity via $\mathrm{ER} \alpha$ in genetically modified mouse models. ${ }^{20}$ However, in these studies, it was only $\mathrm{D}_{4}$, and not the other common cyclic $\left(\mathrm{D}_{3}, \mathrm{D}_{5}, \mathrm{D}_{6}\right.$, or $\left.\mathrm{D}_{4}^{\mathrm{Ph}}\right)$ or acyclic siloxanes, which elicited immune responses that were significantly greater than control experiments. Despite potential health detriments related to $\mathrm{D}_{4}$, non-permethylated cyclosiloxane scaffolds are still of interest for developing new polymeric materials.

Polymers with defined three-dimensional architectures have been produced using a variety of catalysts with the aim of 
controlling morphology and polydispersity. Titanium and dialkyl tin complexes have been used in the synthesis of branched polyesters. ${ }^{21-23}$ Lipase catalysis was first used by Skaria et al. to generate branched polymers from $\varepsilon$-caprolactone and 2,2-bis(hydroxymethyl)butyric acid. ${ }^{23}$ Kulshrestha et al. employed immobilized lipase B from Candida antarctica (CalB) in the synthesis of glycerol-based copolyesters from adipic acid, octan-1,8-diol and glycerol under solvent-free conditions. ${ }^{7}$ While the enzyme catalyst was regioselective for the primary alcohol of glycerol, the degree of branching could be varied between $9-58 \%$ by controlling the feed ratio of the glycerol. Branched polymeric triglyceride analogs derived from oleic diacid, linoleic acid, and glycerol were produced using an enzymatic method..$^{24}$ In the absence of linoleic acid, the mass of the oleic diacid-co-glycerol polymer was greatest at $M_{\mathrm{n}}=12300$ $\mathrm{g} \mathrm{mol}^{-1}$. Increasing the mole fraction of linoleic acid to 0.33 , 0.67 and 1.0 decreased the average mass of the polymer to $M_{\mathrm{n}}=$ $11000 \mathrm{~g} \mathrm{~mol}^{-1}$. The amount of linoleic acid that was incorporated into the polymer increased from 8 to 33, 65, and $92 \mathrm{~mol} \%$ despite the unchanging mass values.

Siloxane-derived materials, and in particular dimethyl siloxanes, have unique physicochemical properties, such as resistance to oxidation, low permittivity, hydrophobicity, permeability to oxygen, low glass transition temperature, and bio-compatibility. ${ }^{25-28}$ Branched and cross-linked siloxanes are prepared via hydrosilylation of $\pi$-bonds using one of several commercially available Pt or Rh catalysts. Peroxide-induced free radical polymerization of acetoxy- or alkoxy-silanes, ${ }^{29}$ photo initiated polymerization, ${ }^{30}$ and tris(pentafluoroborane) catalysis $^{31-33}$ have been used to prepare a diverse range of siloxane architectures.

Polyesters and polyamides have been synthesized using lipase catalysis. ${ }^{34-44}$ When at least one of the monomers was siloxane-derived, a degree of thermal protection could be imparted to the enzyme thus allowing it to be used at temperatures up to $130{ }^{\circ} \mathrm{C}$ without a significant loss in catalytic activity. ${ }^{\mathbf{4 2 , 4 5}}$ The chain length selectivity of CalB towards trisiloxane-containing esters highlighted the importance of steric interactions in terms of choosing appropriate substrates for a given enzyme catalyst. Increasing the distance between the silicon atom and the catalytic serine residue within the active site such that the main chain of the trisiloxane was located just beyond the edge of the cavity containing the active site facilitated the transesterification of methyl esters. ${ }^{44}$

Nanostructured siloxane materials based on cyclotetrasiloxane rings and cubic octamers are gaining popularity resulting from the prospect of tailoring the spatial arrangement of functional groups. ${ }^{\mathbf{4 6}, 47}$ To our knowledge only a few examples exist in the literature which document the enzymatic modification of oligocyclosiloxanes, silsesquioxanes, or spherosilicate cubic octamers. Ihara et al. reported the horseradish peroxidase-mediated synthesis of a silsesquioxane-catechin conjugate using hydrogen peroxide as the oxidant. ${ }^{48}$ The catechin was determined to be tethered to the substituted silsesquioxane in a non-specific manner.

Herein we report the synthesis of siloxane oligoesters based on a cyclotetrasiloxane architectural scaffold using Novozym-
435 to catalyze the condensation oligomerization. Chain length selectivity studies were initially carried out to ascertain how the chain length of the pendant ester contributed to the overall performance of the enzyme catalyst. The resulting oligomers were characterized by nuclear magnetic resonance (NMR) spectroscopy, gel permeation chromatography (GPC), and matrix assisted laser desorption ionization time of flight mass spectroscopy (MALDI-ToF MS). A discussion of the evolution of the individual oligomer species is presented as it pertains to the enzymatic oligomerization.

\section{Experimental}

\section{Materials}

1,3,5,7-Tetramethylcyclotetrasiloxane $\left(\mathrm{D}_{4}^{\mathrm{H}}, 98 \%\right.$ pure $)$, Karstedt's platinum catalyst complex ( $\mathrm{Pt}^{0}$-1,3-divinyl-1,1,3,3tetramethyldisiloxane dimer) $2 \%$ in xylenes, lipase $\mathrm{B}$ from Candida antarctica (EC 3.1.1.3, $6000 \mathrm{U} \mathrm{g}^{-1}$ ) immobilized on Lewatit VP OC 1600 cross-linked divinylbenzene resin (Novozym-435®, N435®), methyl 4-pentenoate (95\% pure), methyl 5-hexenoate (95\% pure), methyl 6-heptenoate (95\% pure), 7-octenoic acid (95\% pure) and 9-decenoic acid (95\% pure) were obtained from Sigma-Aldrich (Oakville, Ontario, Canada). Octan-1-ol (99\%) and octane-1,8-diol (98\% pure) were obtained from Alpha Aesar (Ward Hill, New Jersey, USA). Deuterated chloroform $\left(\mathrm{CDCl}_{3}, 99.9 \%\right.$ deuterated) was obtained from Cambridge Isotope Laboratories (Andover, Maryland, USA). All other organic solvents were of the highest available grade and were stored over 4 Å molecular sieves before use.

\section{Chain length selectivity - esterification of octan-1-ol}

The chain length selectivity of N435 towards cyclotetrasiloxanecontaining esters was determined by combining each ester with a stoichiometric amount of octan-1-ol (1:4 mol ratio) so that the concentration of the $\mathrm{D}_{4}$ ester was $160 \mathrm{mM}$ in toluene. A $5 \mathrm{~mL}$ round bottomed flask was charged with the reactants that were subsequently dissolved in toluene and preheated to $100{ }^{\circ} \mathrm{C}$ in an oil bath that was temperature regulated using a thermostat; the reaction mixture was stirred at $150 \mathrm{rpm}$ with the aid of a Teflon®-coated magnetic stirring bar. The reaction was initiated by adding $5 \mathrm{wt} \%$ (with respect to the total mass of the monomers) of N435. Each assay was conducted for $2 \mathrm{~h}$ at $100{ }^{\circ} \mathrm{C}$; enzymefree reactions were prepared in the same way but without the addition of any enzyme catalyst. Filtering the reaction mixture to remove the immobilized enzyme terminated the reaction. The acrylic beads were subsequently rinsed with $5 \mathrm{~mL}$ of toluene and the solvent was removed under reduced pressure. Consumption of the methyl esters was monitored using ${ }^{1} \mathrm{H}$ NMR as described previously. ${ }^{43}$ The percent conversion of the methyl esters for each set of experiments was reported as the average of four replicate trials.

\section{Polymerization of octane-1,8-diol with $\mathrm{C}_{10}$-cyclotetrasiloxane}

For a typical polymerization, a cooled, $10 \mathrm{~mL}$ flame-dried round bottomed flask was charged with $171 \mathrm{mg}\left(1.75 \times 10^{-4} \mathrm{~mol}\right)$ of 11 
and $52 \mathrm{mg}\left(3.53 \times 10^{-4} \mathrm{~mol}\right)$ of octane-1,8-diol (12) and melted to form a homogeneous mixture at $100{ }^{\circ} \mathrm{C}$ for $5 \mathrm{~min}$ with stirring using a magnetic stirring bar. $\mathrm{N} 435 \AA(5 \mathrm{wt} \%$ relative to the combined mass of the monomers) was added to the reaction mixture with continuous stirring. The flask was capped with a vacuum adapter to allow for the passive evaporation of methanol and was stirred for between $24-120 \mathrm{~h}$. The reactions that were permitted to run for $120 \mathrm{~h}$ were stopped because the viscosity of the reaction mixture was so great that the stir bar ceased stirring. Upon termination of the reaction, each reaction was diluted with $10 \mathrm{~mL}$ of room temperature $\mathrm{CHCl}_{3}$ and stirred for $10 \mathrm{~min}$. The N435 beads were removed by filtering the reaction mixture through a medium porosity glass fritted Buchner funnel. The beads were rinsed with two volumes of $10 \mathrm{~mL}$ of $\mathrm{CHCl}_{3}$ and the excess solvent was removed in vacuo.

\section{1,3,5,7-Tetrakis(4-carboxybutyl)-1,3,5,7- tetramethylcyclotetrasiloxane tetramethyl ester (7)}

To a stirred solution of methyl 4-pentenoate $(793 \mathrm{mg}, 800 \mu \mathrm{L}$, $6.2 \times 10^{-3} \mathrm{~mol}$ ) in $10 \mathrm{~mL}$ of toluene were added $20 \mu \mathrm{L}$ of Karstedt's platinum catalyst in xylenes; the reaction mixture was stirred at room temperature for $5 \mathrm{~min}$. To this were added $337 \mathrm{mg}\left(340 \mu \mathrm{L}, 1.4 \times 10^{-3} \mathrm{~mol}\right)$ of 1,3,5,7-tetramethylcyclotetrasiloxane in a drop-wise manner over $10 \mathrm{~min}$, after which time the reaction flask and contents were heated to reflux for $2.5 \mathrm{~h}$. The reaction mixture was cooled to room temperature and subsequently diluted with $10 \mathrm{~mL}$ of toluene and decolourized with activated carbon for $18 \mathrm{~h}$. The activated carbon was removed by filtering the reaction mixture through Celite ${ }^{\circledR}$ and the crude reaction product was purified by flash column chromatography on silica gel (200-400 mesh) and eluted with hexanes-ethyl acetate increasing the polarity from $10 \%$ to $50 \%$ ethyl acetate to yield $777.0 \mathrm{mg}\left(1.02 \times 10^{-3} \mathrm{~mol}, 73 \%\right)$ of a clear, colourless oil. ${ }^{1} \mathrm{H}$ NMR $\left(300 \mathrm{MHz}, \mathrm{CDCl}_{3}\right): \delta 0.06(\mathrm{~s}, 12 \mathrm{H}), 0.52$ $(\mathrm{m}, 8 \mathrm{H}), 1.37(\mathrm{~m}, 8 \mathrm{H}), 1.6(\mathrm{~m}, 8 \mathrm{H}), 2.30(\mathrm{t}, 8 \mathrm{H}, J=6 \mathrm{~Hz}), 3.66(\mathrm{~s}$, $12 \mathrm{H}) ;{ }^{13} \mathrm{C} \mathrm{NMR}\left(75 \mathrm{MHz}, \mathrm{CDCl}_{3}\right): \delta-0.7,16.8,22.6,28.2,33.8$, 51.4, 174.2; ${ }^{29} \mathrm{Si}$ NMR (59.6 MHz, $\left.\mathrm{CDCl}_{3}\right): \delta-20.2$; EI-MS $(\mathrm{m} / \mathrm{z})$ : $\mathrm{M}^{+}$696; FTIR (KBr, $2 \mathrm{~cm}^{-1}$ ): 748, 800, 1075, 1199, 1260, 1437, $1741,2862,2875,2933,2952$. Analytical calculated for $\mathrm{C}_{28} \mathrm{H}_{56} \mathrm{O}_{12} \mathrm{Si}_{4}$ : C 48.24, $\mathrm{H} 8.10$; found: C 48.59, $\mathrm{H}$ 8.17.

\section{1,3,5,7-Tetrakis(5-carboxypentyl)-1,3,5,7- tetramethylcyclotetrasiloxane tetramethyl ester (8)}

To a stirred solution of methyl 5-hexenoate $(718 \mathrm{mg}, 800 \mu \mathrm{L}$, $5.61 \times 10^{-3} \mathrm{~mol}$ ) in $10 \mathrm{~mL}$ of toluene were added $10 \mu \mathrm{L}$ of Karstedt's platinum catalyst in xylenes; the reaction mixture was stirred at room temperature for $5 \mathrm{~min}$. To this solution were added $317 \mathrm{mg}\left(320 \mu \mathrm{L}, 1.32 \times 10^{-3} \mathrm{~mol}\right)$ of 1,3,5,7-tetramethylcyclotetrasiloxane in a drop-wise manner over $10 \mathrm{~min}$, after which the reaction flask and contents were heated to reflux for $1.5 \mathrm{~h}$. The reaction mixture was cooled to room temperature and subsequently diluted with $10 \mathrm{~mL}$ of toluene and decolourized with activated carbon for $18 \mathrm{~h}$. The activated carbon was removed by filtering the reaction mixture through Celite and the crude reaction product was purified by flash column chromatography on silica gel (200-400 mesh) and eluted with hexanes- ethyl acetate increasing the polarity from $5 \%$ to $50 \%$ ethyl acetate to yield $595 \mathrm{mg}\left(7.36 \times 10^{-4} \mathrm{~mol}, 81 \%\right)$ of a clear, colourless oil. ${ }^{1} \mathrm{H}$ NMR (300 $\left.\mathrm{MHz}, \mathrm{CDCl}_{3}\right): \delta 0.05(\mathrm{~s}, 12 \mathrm{H}), 0.51$ $(\mathrm{m}, 8 \mathrm{H}), 1.33(\mathrm{br}, 24 \mathrm{H}), 1.62(\mathrm{~m}, 8 \mathrm{H}), 2.30(\mathrm{t}, 8 \mathrm{H}, J=9 \mathrm{~Hz}), 3.66$ $(\mathrm{s}, 12 \mathrm{H}) ;{ }^{13} \mathrm{C} \mathrm{NMR}\left(75 \mathrm{MHz}, \mathrm{CDCl}_{3}\right): \delta-0.7,17.0,22.6,24.7,32.6$, 34.0, 51.4, 174.2; ${ }^{29} \mathrm{Si} \mathrm{NMR} \mathrm{(59.6} \mathrm{MHz}, \mathrm{CDCl}_{3}$ ): $\delta-20.2$; EI-MS $(\mathrm{m} / \mathrm{z}):\left(\mathrm{M}-\mathrm{CH}_{3}\right)^{+} 738$; FTIR $\left(\mathrm{KBr}, 2 \mathrm{~cm}^{-1}\right): 801,1081,1196$, $1258,1436,1742,2858,2930,2951$. Analytical calculated for $\mathrm{C}_{32} \mathrm{H}_{64} \mathrm{O}_{12} \mathrm{Si}_{4}$ : C 51.03, $\mathrm{H}$ 8.56; found: C 51.31, H 8.65.

\section{1,3,5,7-Tetrakis(6-carboxyhexyl)-1,3,5,7- tetramethylcyclotetrasiloxane tetramethyl ester (9)}

To a stirred solution of methyl 6-heptenoate $(591 \mathrm{mg}, 650 \mu \mathrm{L}$, $4.16 \times 10-3 \mathrm{~mol}$ ) in $10 \mathrm{~mL}$ of toluene were added $20 \mu \mathrm{L}$ of Karstedt's platinum catalyst in xylenes; the reaction mixture was stirred at room temperature for $5 \mathrm{~min}$. At this time $218 \mathrm{mg}$ $(220 \mu \mathrm{L}, 9.08 \times 10-4 \mathrm{~mol})$ of 1,3,5,7-tetramethylcyclotetrasiloxane were added in a drop-wise manner over $10 \mathrm{~min}$. The contents of the reaction flask were heated to reflux for $18 \mathrm{~h}$. The cooled reaction mixture was diluted with an additional $10 \mathrm{~mL}$ of toluene and decolourized with activated carbon at room temperature for $2 \mathrm{~h}$. The activated carbon was removed by filtering the reaction mixture through Celite and the crude reaction product was purified by flash column chromatography on silica gel (200-400 mesh) and eluted with hexanes-ethyl acetate increasing the polarity from $5 \%$ to $50 \%$ ethyl acetate to yield $596 \mathrm{mg}\left(7.36 \times 10^{-4} \mathrm{~mol}, 81 \%\right)$ of a clear, colourless oil. ${ }^{1} \mathrm{H}$ NMR (300 MHz, $\left.\mathrm{CDCl}_{3}\right): \delta 0.05(\mathrm{~s}, 12 \mathrm{H}), 0.50(\mathrm{~m}, 8 \mathrm{H}), 1.31$ (br, 24H), $1.61(\mathrm{~m}, 8 \mathrm{H}), 2.30(\mathrm{t}, 8 \mathrm{H}, J=9 \mathrm{~Hz}), 3.66(\mathrm{~s}, 12 \mathrm{H}) ;{ }^{13} \mathrm{C}$ NMR (75 $\left.\mathrm{MHz}, \mathrm{CDCl}_{3}\right): \delta-0.6,17.5,22.8,24.9,29.0,32.8,34.1$, 51.4, 174.2; ${ }^{29} \mathrm{Si}$ NMR (59.6 MHz, $\left.\mathrm{CDCl}_{3}\right): \delta-20.2,-20.3$; EI-MS $(\mathrm{m} / \mathrm{z}):\left(\mathrm{M}-\mathrm{CH}_{3}\right)^{+}$793; FTIR $\left(\mathrm{KBr}, 2 \mathrm{~cm}^{-1}\right): 800,1072,1176$, 1194, 1259, 1436, 1742, 2857, 2924. Analytical calculated for $\mathrm{C}_{36} \mathrm{H}_{72} \mathrm{O}_{12} \mathrm{Si}_{4}$ : C 53.43, H 8.97; found: C 53.69, H 9.09.

\section{1,3,5,7-Tetrakis(7-carboxyheptyl)-1,3,5,7- tetramethylcyclotetrasiloxane tetramethyl ester (10)}

To a stirred solution of methyl 7-octenoate $(578 \mathrm{mg}, 650 \mu \mathrm{L}$, $3.70 \times 10^{-3} \mathrm{~mol}$ ) in $10 \mathrm{~mL}$ of toluene were added $10 \mu \mathrm{L}$ of Karstedt's platinum catalyst in xylenes; the reaction mixture was stirred at room temperature for $5 \mathrm{~min}$. To this solution were added $191 \mathrm{mg}\left(210 \mu \mathrm{L}, 7.96 \times 10^{-4} \mathrm{~mol}\right)$ of 1,3,5,7-tetramethylcyclotetrasiloxane in a drop-wise manner over 10 min after which the reactants were heated to reflux for $2 \mathrm{~h}$. The reaction mixture was cooled to room temperature and diluted with a further $10 \mathrm{~mL}$ of toluene and decolourized with activated carbon at room temperature for $18 \mathrm{~h}$. The activated carbon was removed by filtering the reaction mixture through Celite and the crude reaction product was purified by flash column chromatography on silica gel (200-400 mesh) and eluted with hexanesethyl acetate increasing the polarity from $10 \%$ to $33 \%$ ethyl acetate to yield $404 \mathrm{mg}(4.67 \times 10-4 \mathrm{~mol}, 59 \%)$ of a clear, colourless oil. ${ }^{1} \mathrm{H}$ NMR (300 $\left.\mathrm{MHz}, \mathrm{CDCl}_{3}\right): \delta 0.05(\mathrm{~s}, 12 \mathrm{H}), 0.50$ $(\mathrm{m}, 8 \mathrm{H}), 1.30(\mathrm{br}, 32 \mathrm{H}), 1.62(\mathrm{~m}, 8 \mathrm{H}), 2.30(\mathrm{t}, 8 \mathrm{H}, J=6 \mathrm{~Hz}), 3.66$ $(\mathrm{s}, 12 \mathrm{H}) ;{ }^{13} \mathrm{C} \mathrm{NMR}\left(75 \mathrm{MHz}, \mathrm{CDCl}_{3}\right): \delta-0.6,17.1,22.9,25.0,29.0$, 29.1, 32.9, 34.1, 51.4, 174.3; ${ }^{29} \mathrm{Si} \mathrm{NMR}\left(59.6 \mathrm{MHz}, \mathrm{CDCl}_{3}\right): \delta$ 
-20.2; EI-MS ( $\mathrm{m} / \mathrm{z}):\left(\mathrm{M}-\mathrm{CH}_{3}\right)^{+}$849; FTIR ( $\left.\mathrm{KBr}, 2 \mathrm{~cm}^{-1}\right): 800$, 1072, 1086, 1175, 1259, 1436, 1743, 2855, 2927, 2950. Analytical calculated for $\mathrm{C}_{40} \mathrm{H}_{80} \mathrm{O}_{12} \mathrm{Si}_{4}$ : C 55.52, H 9.32; found: C 55.67, H 9.29.

\section{1,3,5,7-Tetrakis(9-carboxynonyl)-1,3,5,7-}

\section{tetramethylcyclotetrasiloxane tetramethyl ester (11)}

To a stirred solution of methyl 9-decenoate $(1.4 \mathrm{~g}, 1.6 \mathrm{~mL}, 7.43 \times$ $10^{-3} \mathrm{~mol}$ ) in $10 \mathrm{~mL}$ of toluene were added $10 \mu \mathrm{L}$ of Karstedt's platinum catalyst in xylenes; the reaction mixture was stirred at room temperature for $5 \mathrm{~min}$. To this were added $396 \mathrm{mg}$ (400 $\mu \mathrm{L}, 1.65 \times 10^{-3} \mathrm{~mol}$ ) of 1,3,5,7-tetramethylcyclotetrasiloxane in a drop-wise manner over $10 \mathrm{~min}$ after which the reaction flask and contents were heated to reflux for $2 \mathrm{~h}$. The reaction mixture was cooled to room temperature and diluted with a further 10 $\mathrm{mL}$ of toluene and decolourized with activated carbon for $18 \mathrm{~h}$. The activated carbon was removed by filtering the reaction mixture through Celite and the crude reaction product was purified by flash column chromatography on silica gel (200-400 mesh) and eluted with hexanes-ethyl acetate increasing the polarity from $10 \%$ to $33 \%$ ethyl acetate to yield $931 \mathrm{mg}(9.54 \times$ $\left.10^{-4} \mathrm{~mol}, 58 \%\right)$ of a clear, colourless oil. ${ }^{1} \mathrm{H}$ NMR $(300 \mathrm{MHz}$, $\left.\mathrm{CDCl}_{3}\right): \delta 0.05(\mathrm{~s}, 12 \mathrm{H}), 0.50(\mathrm{~m}, 8 \mathrm{H}), 1.27(\mathrm{br}, 48 \mathrm{H}), 1.61(\mathrm{~m}, 8 \mathrm{H})$, $2.30(\mathrm{t}, 8 \mathrm{H}, J=6 \mathrm{~Hz}), 3.66(\mathrm{~s}, 12 \mathrm{H}) ;{ }^{13} \mathrm{C} \mathrm{NMR}\left(75 \mathrm{MHz}, \mathrm{CDCl}_{3}\right): \delta$ $-0.6,17.2,23.0,25.0,29.2,29.3,29.41,29.43,33.2,34.1,51.4$, $174.5 ;{ }^{29} \mathrm{Si}$ NMR (59.6 MHz, $\left.\mathrm{CDCl}_{3}\right): \delta-20.2$; EI-MS $(\mathrm{m} / \mathrm{z})$ : $\left(\mathrm{M}-\mathrm{CH}_{3}\right)^{+}$961; FTIR (KBr, $\left.2 \mathrm{~cm}^{-1}\right): 800,1071,1086,1172,1196$, 1258, 1436, 1462, 1745, 2855, 2927. Analytical calculated for $\mathrm{C}_{48} \mathrm{H}_{96} \mathrm{O}_{12} \mathrm{Si}_{4}$ : C 58.97, H 9.90; found: C 59.12, H 9.92.

\section{Instrumentation}

Nuclear magnetic resonance (NMR) spectroscopy. NMR spectra $\left({ }^{1} \mathrm{H}(300 \mathrm{MHz}),{ }^{13} \mathrm{C}(75 \mathrm{MHz}),{ }^{29} \mathrm{Si}(59.6 \mathrm{MHz})\right)$ were recorded on a Bruker Avance AV-300 nuclear magnetic resonance spectrometer equipped with a BB-PABBO probe. ${ }^{1} \mathrm{H}$ and ${ }^{13} \mathrm{C}$ NMR spectra were referenced to the residual protons of $\mathrm{CHCl}_{3}$ (7.26 ppm) in $\mathrm{CDCl}_{3}$ and ${ }^{29} \mathrm{Si}$ NMR spectra were referenced to tetramethylsilane $(0.0 \mathrm{ppm})$.

Fourier-transform infrared spectra (FT-IR). FT-IR were obtained using a Mattson Research Series infrared spectrometer operating in transmission mode. Each spectrum consisted of 32 scans at a resolution of $2 \mathrm{~cm}^{-1}$.

Mass spectrometry. Electrospray ionization mass spectrometry (EI-MS) was carried out using a Kratos Concept 1S High Resolution E/B mass spectrometer in negative ion mode. MALDI-ToF MS spectra were acquired on a Bruker Autoflex MALDI-ToF mass spectrometer in the positive ion mode. Samples were dissolved into HPLC grade THF or acetone, sonicated, and combined with a $\mathrm{NaCl} / \mathrm{THF}$ (acetone) mixture and sonicated a second time. A small sample was transferred to a stainless steel plate that was preloaded with a paste composed of dithranol/THF.

Gel permeation chromatography (GPC). Polymer molecular weights and dispersity indices $(D)$ (relative to polystyrene standards) were analyzed via GPC using a Waters 2695 Separations Module equipped with a Waters 2414 refractive index detector, a
Waters 2996 photodiode array detector, and three Jordi Fluorinated DVB mixed bed columns. THF was used as the eluent at a flow rate of $1.0 \mathrm{~mL} \mathrm{~min}^{-1}$.

\section{Results and discussion}

\section{Synthesis of $\mathrm{D}_{4}$ esters}

Cyclotetrasiloxane esters (7-11) were synthesized via platinumcatalysed hydrosilylation chemistry using the commercially available Karstedt's platinum catalyst complex in xylenes, and were isolated after flash chromatography on silica gel in moderate to good yields (Fig. 1). The structures of esters 7-11 were in good agreement with previously published data. ${ }^{44}{ }^{29} \mathrm{Si}$ NMR spectroscopy revealed multiple ${ }^{29} \mathrm{Si}$ resonances indicating a mixture of isomers of the $\mathrm{D}_{4}$ ring system. ${ }^{49}$ These isomers were confirmed to have been present in the $\mathrm{D}_{4}^{\mathrm{H}}$ starting material and did not result from the platinum-catalysed hydrosilylation chemistry. Esters 7-11 were shown to contain exclusively the anti-Markovnikov hydrosilylation adduct as determined by ${ }^{1} \mathrm{H}$ NMR.

\section{Chain length selectivity}

Increasing the steric bulk of the coupling partners in enzymatic polyesterification reactions can dramatically affect the rate of chain elongation, as well as the average molecular mass of the final polymer. Architectural aspects within the active site of the enzyme contribute to the yield and selectivity of a given enzymatic reaction. Increasing the distance between a trisiloxane moiety and the carbonyl carbon of trisiloxane-containing esters resulted in increased transesterification. ${ }^{44}$ In line with the previous results, the incorporation of $\mathrm{C}_{5}-\mathrm{C}_{8}$ and $\mathrm{C}_{10}$ esters into a cyclic siloxane framework (Fig. 2) showed a corresponding increase in conversion with chain length (Fig. 2). The consumption of methyl esters was greatest with decanoate esters (66\% conversion) appended to the $\mathrm{D}_{4}$ ring system. The dimensions of the active site of CalB are $9.5 \AA \times 4.5 \AA{ }^{50}$ which puts the siloxane fragment of $\mathrm{C} 7$ or larger esters outside of the active site. ${ }^{44}$ However, the heptanoate ( $4.5 \%$ consumption) and octanoate $(13.5 \%$ consumption) esters were problematic substrates for the CalB enzyme. These particular $\mathrm{D}_{4}$-rings exhibited a less favourable interaction with the enzyme compared to the earlier investigation. ${ }^{43}$ This is attributable to the added steric contribution of the larger $\mathrm{D}_{4}$ ring system, which occluded entry into the active site of the enzyme. The smallest of the esters, containing pentanoate ( $2 \%$ consumption), and hexanoate esters $(2.5 \%$ consumption) showed very low levels of

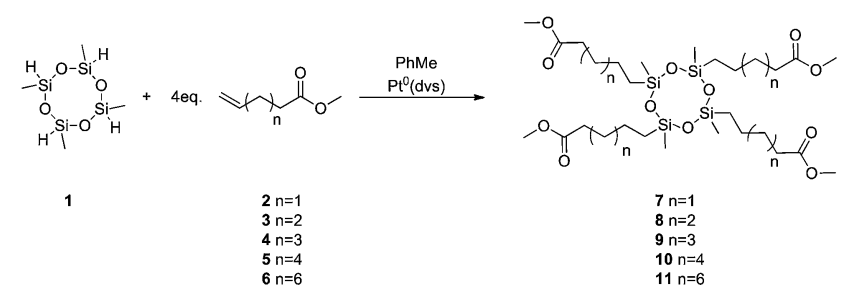

Fig. 1 Synthesis of ester-functionalized cyclotetrasiloxane rings. 

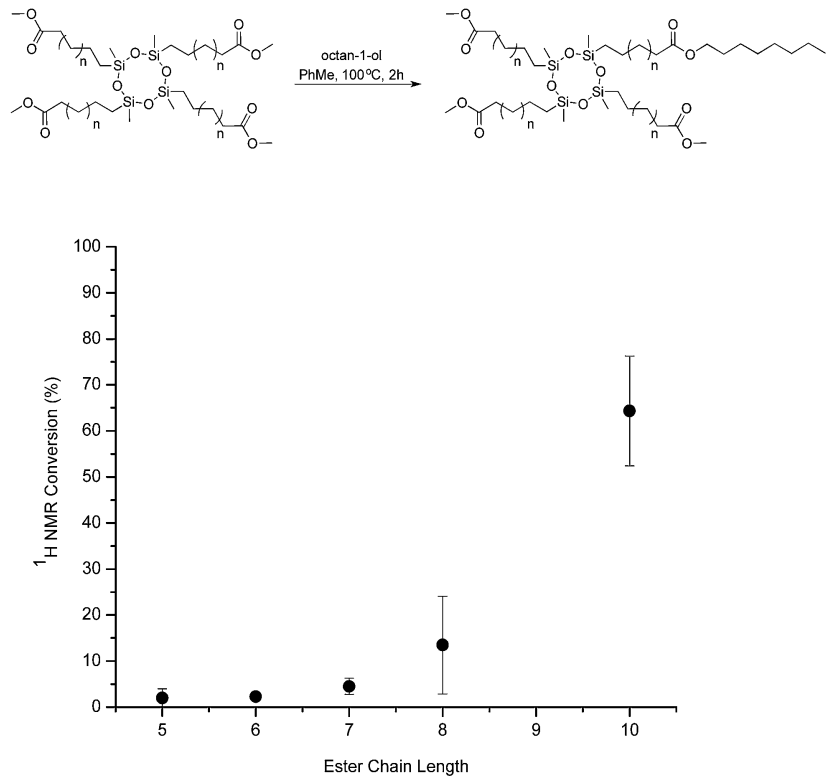

Fig. 2 Determination of chain length preference of N435 for esterfunctionalized cyclotetrasiloxanes. The enzymatic (N435) conversion of cyclotetrasiloxane methyl esters. Each data point represents the average of three replicate trials; error bars indicate the standard error of replicate trials.

transesterification. Despite the small differences between this study and our previous work, the general trend agrees well. ${ }^{\mathbf{4 4}}$

\section{Oligomerization of cyclotetrasiloxane esters with diols}

Based on the results from the chain length selectivity studies, esters 9 and $\mathbf{1 1}$ were chosen as candidates for enzymatic oligomerization experiments (Fig. 3). As previously mentioned, the $\mathrm{C}_{7} \mathrm{D}_{4}$ ester places the silicon atom of the ring at the interface of the active site, while the longer $\mathrm{C}_{10} \mathrm{D}_{4}$ ester places the cyclosiloxane ring well beyond this limit reducing the influence of steric interference on catalysis.

Enzymatic polymerizations were performed by combining the diol to ester in a $2: 1$ mole ratio in the presence of $5 \mathrm{wt} \%$ of $\mathrm{N} 435$, with respect to the total mass of the monomers, in the

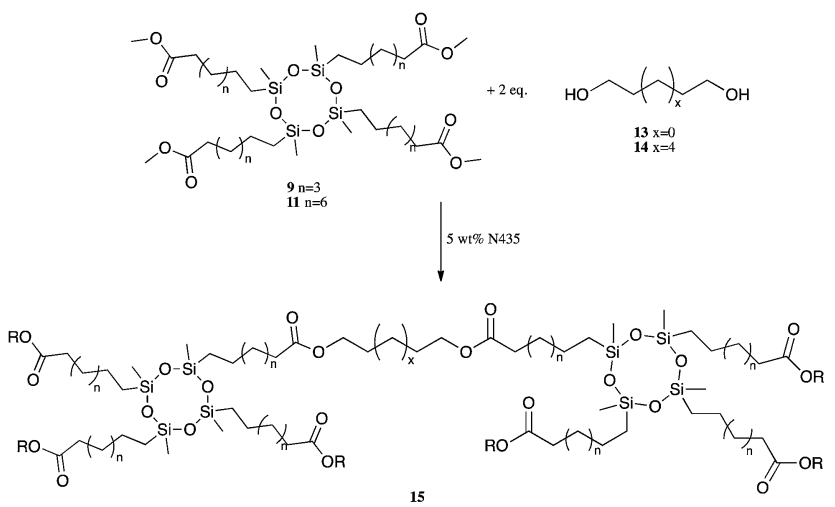

Fig. 3 The enzymatic synthesis of oligoesters derived from cyclotetrasiloxane esters two diols. absence of solvent and under air with magnetic stirring at $100{ }^{\circ} \mathrm{C}$. The unfractionated oligoesters were characterized by NMR spectroscopy, MALDI-ToF MS and gel permeation chromatography (see Experimental section).

The $\mathrm{D}_{4}$ esters, hereafter designated as monomer $\mathbf{A}$, and the diols (monomer B), can be combined in multiple ways owing to the tetra functional nature of the cyclotetrasiloxane ring. For the sake of convenience, the possible combinations of monomers will be assigned a label using a nomenclature based on $\mathrm{A}_{x} \mathrm{~B}_{y}$ where $x$ and $y$ are integers corresponding to the number of each monomer. Where intramolecular transesterification events are believed to have occurred they will be denoted with the suffix cyc $^{n}$ where $n$ refers to the number of intramolecular cyclization events. The identification of esterified components was determined with the aid MALDI-ToF MS spectra. Relative molecular weights were determined using MALDI-ToF MS during the early stages of oligomerization and gel permeation chromatography (GPC) for time periods between 6-72 h.

Representative ${ }^{1} \mathrm{H}$ NMR spectra for ester $\mathbf{1 1}$ and a polyester derived from ester 11 and octane-1,8-diol are presented in Fig. 4. The assigned spectra show the expected line shapes that are associated with alkyl chains attached to silicon atoms. The multiplets at $0.50 \mathrm{ppm}$ and $1.60 \mathrm{ppm}$ are the $\mathrm{C} 1$ and $\mathrm{C} 2$ carbons (with respect to silicon) and show a second order $\mathrm{AA}^{\prime} \mathrm{XX}^{\prime}$ splitting pattern. The broad resonance centered at $1.28 \mathrm{ppm}$ includes all of the methylene groups between C2 and C8. The triplet at $2.30 \mathrm{ppm}$ is indicative of a methylene adjacent to an ester. The intense singlet at $3.66 \mathrm{ppm}$ is for the methyl ester. During esterification, the intensity of the methyl ester decreases, although due to the overlapping resonance at 3.63 ppm from octane-1,8-diol, this cannot be used for monitoring consumption of the ester. A peak at $4.04 \mathrm{ppm}$ appears in the spectra of the polymer indicative of a newly formed octyl ester. The ratio of the integral for this resonance to the resonance at 2.28 ppm was used for determining the amount of the methyl esters that were esterified by the enzyme.

\section{Time course profile}

One of the goals of this study was to gain a more complete understanding of the N435's mode of action during enzymatic oligomerization. A time course profile of the progressing oligomerization was generated over the first six hours of the reaction cycle using different time increments (i.e., 1-10 min, 10-60 min, 1-6 h, $24 \mathrm{~h}$ ). The effect of chain length of the $\mathrm{D}_{4}$ esters and the aliphatic diols on the total conversion of the monomers is presented in Fig. 5. The substrate pair consisting of the two shortest chain length monomers, the $\mathrm{C}_{7} \mathrm{D}_{4}$-ester and pentane-1,5-diol respectively, were not a good substrate pair for CalB. After $1 \mathrm{~h}$, consumption of the methyl ester was low at only $13 \%$. While consumption continued to increase, the inflection point was reached after $4 \mathrm{~h}$ at which time consumption of the methyl esters hovered around $21 \%$. After $24 \mathrm{~h}$ consumption of the ester increased by only $10 \%$ to $31 \%$. Increasing the chain length of the diol to octane-1,8-diol resulted in an increased consumption, reaching $25 \%$ after $1 \mathrm{~h}$; consumption continued to increase during the $24 \mathrm{~h}$ timeframe of the experiment 

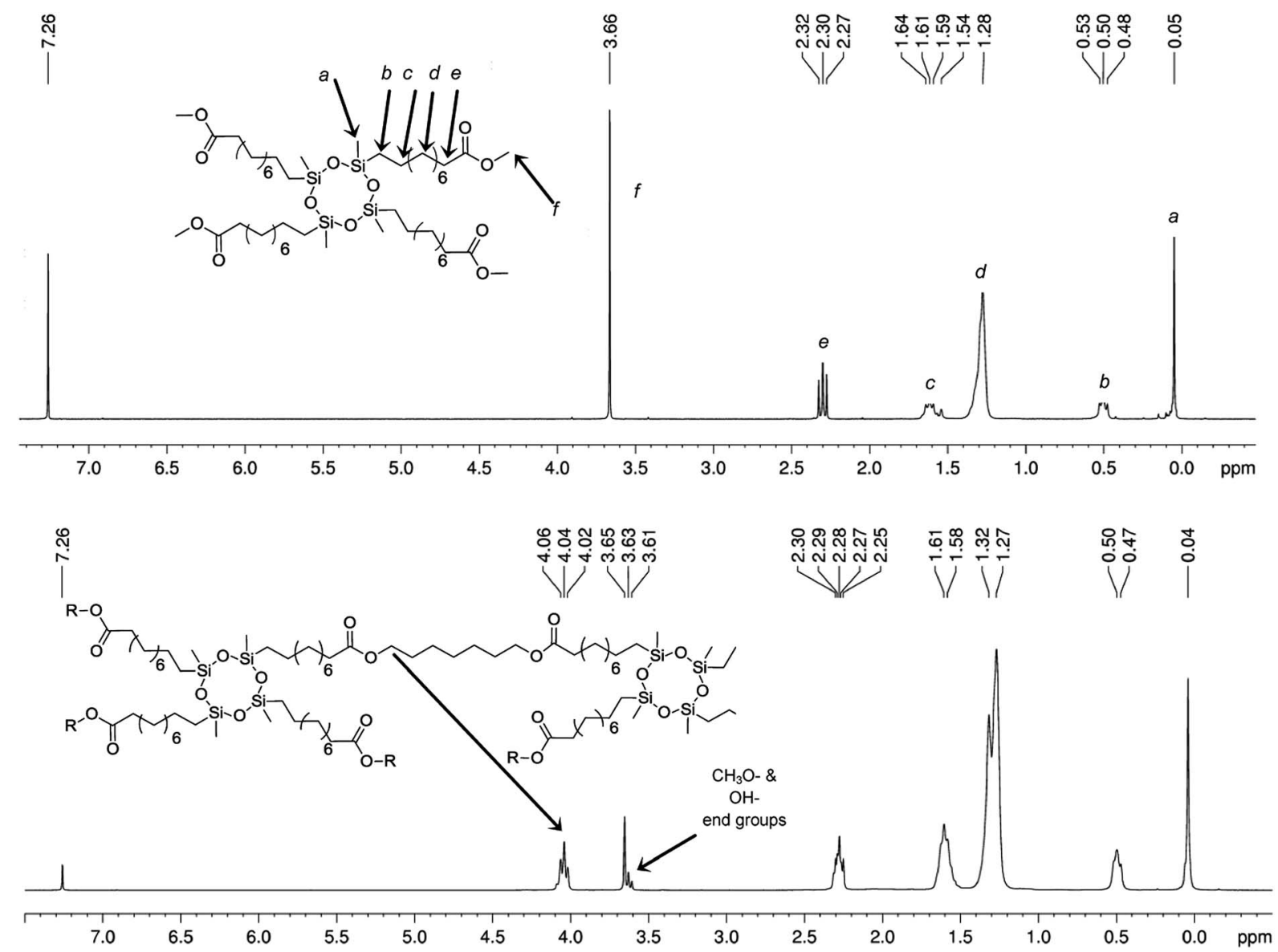

Fig. $4{ }^{1} \mathrm{H}$ NMR spectra of $C_{10} D_{4}$ ester (top) and a polyester derived from $C_{10} D_{4}$ ester and octane-1,8-diol.

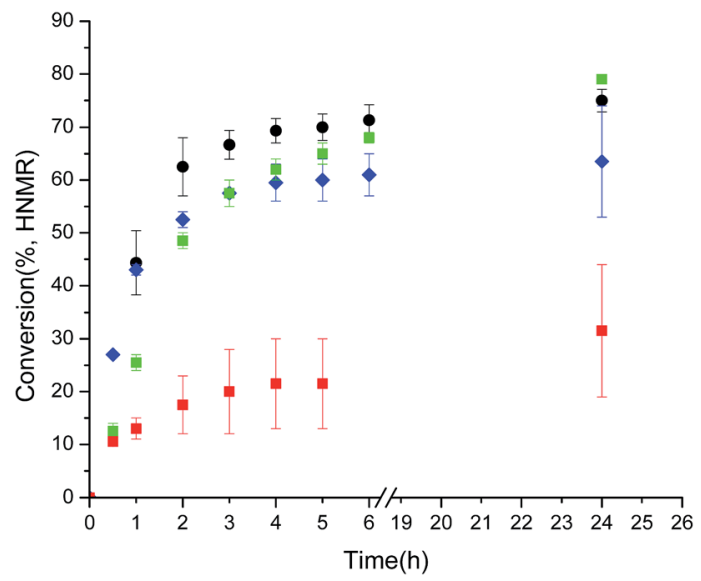

Fig. 5 A time course profile of the N435-catalyzed esterification of ester substituted cyclotetrasiloxanes and two diols. Legend: red squares: $C_{7} D_{4}$-ester and pentane-1,5-diol; green squares: $C_{7} D_{4}$-ester and octane-1,8-diol; blue diamonds: $\mathrm{C}_{10} \mathrm{D}_{4}$-ester and pentane-1,5diol; black circles: $\mathrm{C}_{10} \mathrm{D}_{4}$-ester and octane-1,8-diol. Standard error bars are shown for replicate trials.

reaching a final conversion of $80 \%$. Increasing the chain length of the ester from $\mathrm{C}_{7}$ to $\mathrm{C}_{10}$ was followed by an increase in consumption for each of the two diols. While the initial stages of the reaction were virtually identical, $43 \%$ and $44 \%$ for pentane-1,5-diol and octane-1,8-diol respectively, differences started to emerge after $2 \mathrm{~h}$. Octane-1,8-diol proved to be more effective at releasing the enzyme form its acylated state, showing $63 \%$ conversion compared to only $52 \%$ conversion when pentane-1,5-diol was the acyl acceptor. This $\sim 10 \%$ difference was seen throughout the remainder of the $24 \mathrm{~h}$ timeframe. The results of these experiments, coupled with those from the initial chain length studies show that the chain length of the ester is an important factor in N435-catalysed reactions. The size of the diol cannot be entirely neglected. Previous studies have suggested that smaller diols, with more hydrophilic character, were less suitable for producing high molecular mass polymers from a disiloxane diacid. ${ }^{37}$

\section{MALDI-ToF experiments}

The ${ }^{1} \mathrm{H}$ NMR data was supplemented by MALDI-ToF experiments. Samples removed at the same time points as those for the NMR experiments and were analyzed by MALDI-ToF MS so that we could identify the individual chemical species that were being produced throughout the oligomerization. The distribution of the chemical species obtained from the MALDI-ToF MS experiments was used to model the progress of the enzymecatalyzed polymerizations. This approach was effective during 
the first $6 \mathrm{~h}$ of each reaction as it became difficult to obtain reliable MALDI spectra at longer time periods when higher molecular mass fragments began to constitute a larger fraction of the total distribution of chemical species. Previous work using time of flight mass spectrometry of highly disperse synthetic polymers indicated that higher molecular weight fragments are typically underrepresented compared to lower mass components leading to a lower than expected $M_{\mathrm{n}}$ and $M_{\mathrm{w}}$ values. ${ }^{51}$ This effect has been, at least partially, attributed to mass-dependent desorption/ionization and ion detection. Furthermore, low matrix to polymer mole ratios, particularly those in which highly disperse polymers are being analyzed, are more problematic to analyze due to the low solubility of the polymer by the matrix itself resulting in lower desorption/ ionization. ${ }^{52}$

A pictographic representation of the early stages of oligomerization between $\mathrm{D}_{4}$ esters and diols is presented in Fig. 6 (see ESI $\dagger$ file for representative MALDI spectra of a typical reaction profile). Oligomerization typically progressed by the stepwise addition of a single diol to each of the four ester units of the $\mathrm{D}_{4}$ core. There was evidence for the formation of the $\mathrm{AB}$, $\mathrm{AB}_{2}, \mathrm{AB}_{3}$ esters, and to a much lesser extent, the $\mathrm{AB}_{4}$ fully transesterified species. Regardless of the reacting partners, the complete transesterification of the four ester groups was not an obligate requirement for further oligomerization to higher order species. For example, when dimers are detectable by MALDI, the first observed species correspond to $A_{2} B, A_{2} B_{2}, A_{2} B_{3}$, and $\mathrm{A}_{2} \mathrm{~B}_{4}$ (Fig. 7). These species may be formed via two possible routes; namely the free diol of each of the $\mathrm{AB}_{x}$ monomers may release the enzyme from an acylated state to give the corresponding $\mathrm{A}_{2} \mathrm{~B}_{x}$ dimer, or alternatively, but less frequently according to the available MALDI data, only the $\mathrm{AB}$ monomer acts as an acyl acceptor to give $\mathrm{A}_{2} \mathrm{~B}$ which then becomes further decorated by the addition of diol units. Regardless of which route is dominant, further esterification of $A_{2} B_{4}$ to give $A_{2} B_{5}$ and $\mathrm{A}_{2} \mathrm{~B}_{6}$ likely flows in a linear fashion while the dimerizations of other combinations are possible. Similarly, trimers, when they appear in the MALDI spectrum appeared as $A_{3} B_{3}$ to $A_{3} B_{6}$ before any other trimeric oligomers are detected; again these oligomers were further acted upon by the enzyme to produce more highly modified structures having a linear "centipede-like" architecture. As oligomerization continued, intramolecularly cyclized species become evident in the MALDI spectrum. These events are few, but result when the extent of the reaction increases and the medium becomes more viscous. Two dimensional branched architectures, or even three dimensional structures, are not outside the realm of possibility; however using only MALDI data prohibits any conclusions in this regard.

Permitting the enzyme-mediated oligomerization to continue for $96-120 \mathrm{~h}$ resulted in a clear and colourless gel-like

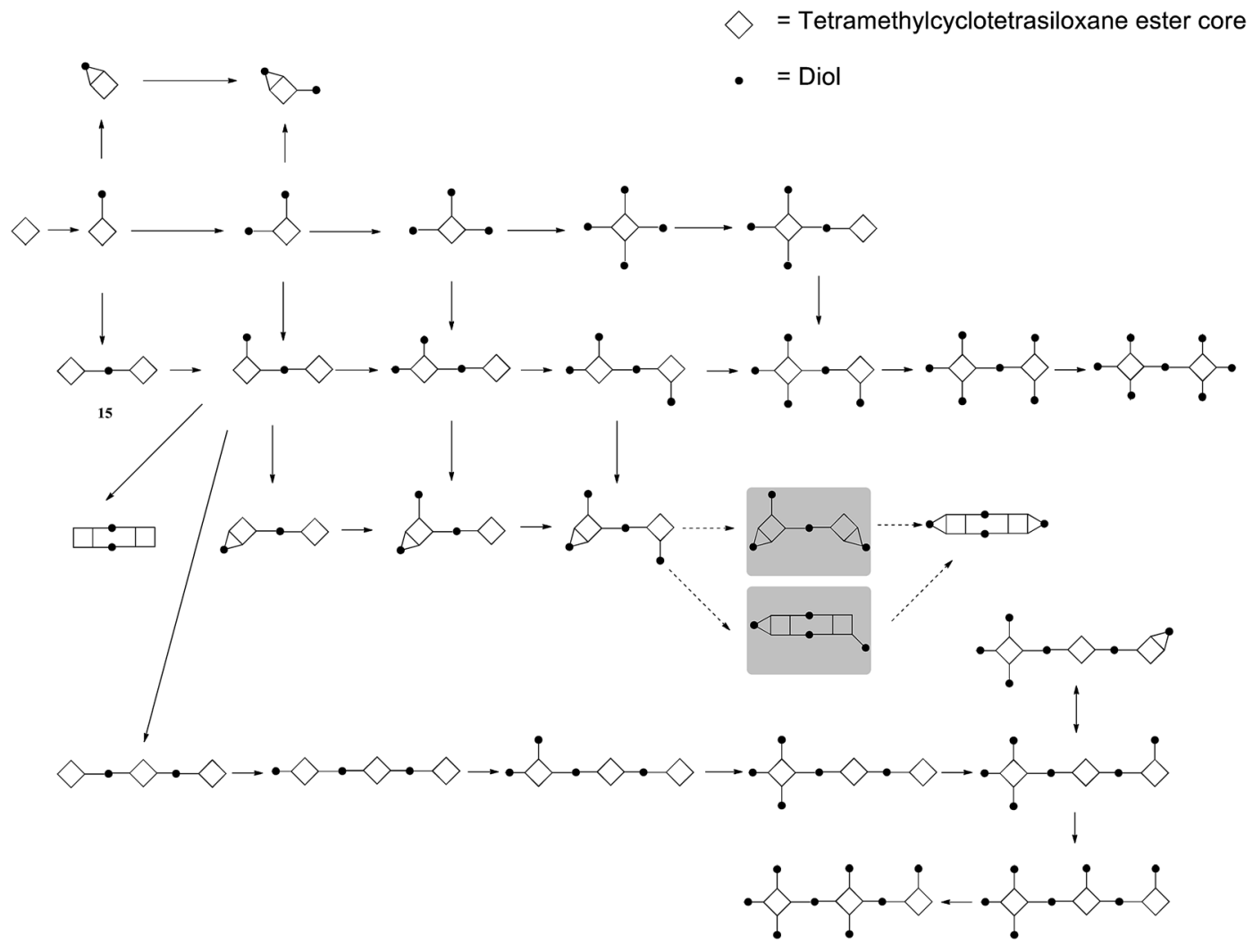

Fig. 6 A pictographic representation of the $\mathrm{N} 435$-catalyzed oligomerization of $\mathrm{D}_{4}$-esters and diols under solvent-free conditions. The diamonds represent the cyclotetrasiloxane core, the black dots the diol unit; the lines between the vertices of the diamond and the dots indicate the bonds between the two molecules. The structure labelled 15 corresponds to the chemical structure of the same number in Fig. 3 as a reference where $\mathrm{R}=\mathrm{Me}$. 


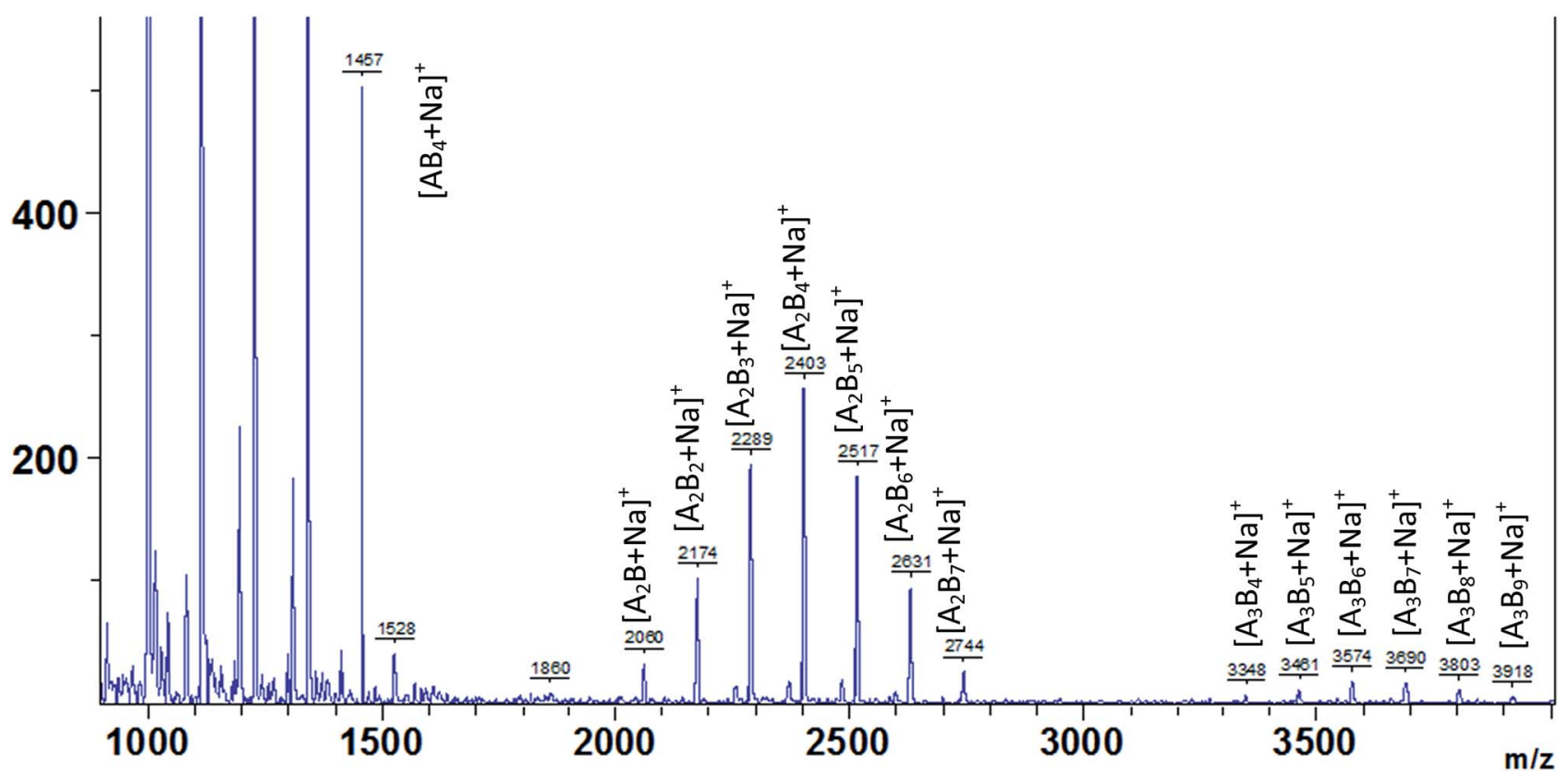

Fig. 7 A representative MALDI-ToF spectra acquired during the polymerization of ester 11 and octane-1,8-diol. The peaks have been identified as the sodiated adducts. See the Experimental section for a description of MALDI-ToF experiment set up.

material that was insoluble in common organic solvents. Gels were not obtained when the $\mathrm{C}_{7} \mathrm{D}_{4}$ ester and pentane-1,5-diol were the reacting partners; this was perhaps the result of low conversions, a mere $45 \%$, after 5 days. The formation of crosslinked gels indicated that the enzyme exhibits a capacity to manipulate the free end-groups of the polymer chains to produce randomly branched architectures.

\section{Gel permeation chromatography of $\mathrm{D}_{4}$ polyesters}

GPC chromatograms for each of the substrate pairs, with the exceptions of the $\mathrm{C}_{7} \mathrm{D}_{4}$-ester/pentane-1,5-diol pair, were acquired and compared against polystyrene (PS) standards. A summary of the growth of $M_{\mathrm{n}}, M_{\mathrm{w}}$ and the change in dispersity $(\nexists)$ of the siloxane-derived oligomers is presented in Table 1. The oligomers produced from octane-1,8-diol and the $\mathrm{C}_{7} \mathrm{D}_{4}$-ester gave low molecular weight oligomers with $M_{\mathrm{n}}=1900 \mathrm{~g} \mathrm{~mol}^{-1}$, $M_{\mathrm{w}}=3100 \mathrm{~g} \mathrm{~mol}^{-1}$, and $\oslash=1.67$ after $6 \mathrm{~h}$. These values increased marginally to $M_{\mathrm{n}}=2300 \mathrm{~g} \mathrm{~mol}^{-1}, M_{\mathrm{w}}=4600 \mathrm{~g} \mathrm{~mol}^{-1}$, and $Ð=1.98$ after $24 \mathrm{~h}$ and $M_{\mathrm{n}}=3000 \mathrm{~g} \mathrm{~mol}^{-1}, M_{\mathrm{w}}=11400 \mathrm{~g} \mathrm{~mol}^{-1}$ and $\oslash=3.77$ after $48 \mathrm{~h}$. After $48 \mathrm{~h}$ the reaction mixture was extremely viscous such that stirring using a conventional magnetic stirring bar was not feasible. Similarly, when the $\mathrm{C}_{10} \mathrm{D}_{4}$-ester and pentane-1,5-diol were paired together, the reaction ceased to stir. For these oligomers $M_{\mathrm{n}}=1900 \mathrm{~g} \mathrm{~mol}^{-1}, M_{\mathrm{w}}=3700 \mathrm{~g} \mathrm{~mol}^{-1}$ and $Ð=1.95$ after $6 \mathrm{~h}, M_{\mathrm{n}}=2550 \mathrm{~g} \mathrm{~mol}^{-1}, M_{\mathrm{w}}=5300 \mathrm{~g} \mathrm{~mol}^{-1}$, and $Ð=2.10$ after $24 \mathrm{~h}$ while $M_{\mathrm{n}}=2900 \mathrm{~g} \mathrm{~mol}^{-1}, M_{\mathrm{w}}=13100 \mathrm{~g} \mathrm{~mol}^{-1}$, and $\oslash=4.57$ after $48 \mathrm{~h}$ were obtained. For the largest monomers, $\mathrm{C}_{10} \mathrm{D}_{4}$-ester and octane-1,8-diol, after $6 \mathrm{~h} M_{\mathrm{n}}=2900 \mathrm{~g} \mathrm{~mol}^{-1}$, $M_{\mathrm{w}}=6700 \mathrm{~g} \mathrm{~mol}^{-1}$, and $\doteq=2.35$. After $24 \mathrm{~h}$, these values increase marginally to $M_{\mathrm{n}}=3100 \mathrm{~g} \mathrm{~mol}^{-1}, M_{\mathrm{w}}=8700 \mathrm{~g} \mathrm{~mol}^{-1}$, and

Table 1 Comparative molecular weight values for reactions of cyclosiloxane-based tetraesters and diol molecules

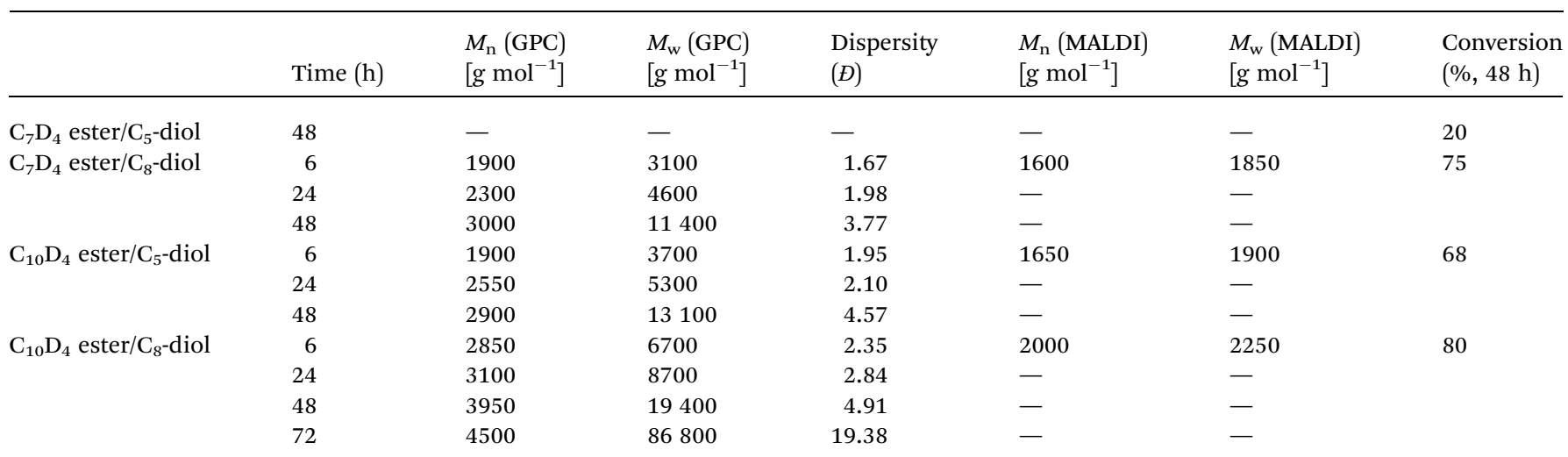


$Ð=2.84$. Beyond $24 \mathrm{~h}$, the distribution of oligomers became more disperse with $M_{\mathrm{n}}=3950 \mathrm{~g} \mathrm{~mol}^{-1}, M_{\mathrm{w}}=19400 \mathrm{~g} \mathrm{~mol}^{-1}$, and $D=$ 4.91 after $48 \mathrm{~h}$, and $M_{\mathrm{n}}=4479 \mathrm{~g} \mathrm{~mol}^{-1}, M_{\mathrm{w}}=86800 \mathrm{~g} \mathrm{~mol}^{-1}$, and $Ð=19.38$ after $72 \mathrm{~h}$.

In general, the growing oligomeric chains, which may have some degree of random branching, gave rise to increasing $\emptyset$-values. These larger $\emptyset$-values need to be taken within the context of the reactions under investigation. While the use of narrow dispersity polystyrene (PS) standards is generally accepted for determining $M_{\mathrm{n}}$ and $M_{\mathrm{w}}$ through gel permeation chromatography, the hydrodynamic radii of the branched polyesters synthesized in these experiments is not accurately represented by PS standards. ${ }^{53}$

\section{Conclusions}

We have examined the lipase-mediated synthesis of polyesters derived from a cyclotetrasiloxane framework in the absence of solvent. The enzymatic oligomerization proceeds via the stepwise addition of the diol units to each of the four arms of the tetraester; this was not an obligate requirement to oligomerization. MALDI-ToF MS, GPC, and ${ }^{1} \mathrm{H}$ NMR data were used to examine the oligomerization of monomers. Oligomerization slowed after $4 \mathrm{~h}$, and further increases in diester consumption were marginal reaching values between $65 \%$ and $80 \%$. Branched polymers with $M_{\mathrm{w}}>11000 \mathrm{~g} \mathrm{~mol} \mathrm{~m}^{-1}$ could be produced in $48 \mathrm{~h}$ at $100{ }^{\circ} \mathrm{C}$. To the best of our knowledge this represents the first attempt to use lipase catalysis to produce branched polymers that contain a cyclotetrasiloxane scaffold.

\section{Acknowledgements}

Funding for this research was provided by the Natural Sciences and Engineering Research Council (NSERC) of Canada and the Brock University Advanced Biomanufacturing Centre and is gratefully acknowledged. The authors would like to thank Prof. A. Adronov (McMaster University) for the acquisition of GPC chromatograms.

\section{Notes and references}

1 K. Matyjaszewski, Macromolecules, 2012, 45, 4015.

2 S. Perrier and P. Takolpuckdee, J. Polym. Sci., Part A: Polym. Chem., 2005, 43, 5347.

3 C. Boyer, V. Bulmus, T. P. Davis, V. Ladmiral, J. Liu and S. Perrier, Chem. Rev., 2009, 109, 5402.

4 P. J. Flory, J. Am. Chem. Soc., 1952, 74, 2718.

5 K. Khanna, S. Varshney and A. Kakkar, Polym. Chem., 2010, 1, 1171.

6 C. Gao and D. Yan, Prog. Polym. Sci., 2004, 29, 183.

7 A. S. Kulshrestha, W. Gao and R. A. Gross, Macromolecules, 2005, 38, 3193.

8 C. J. Hawker, R. Lee and J. M. J. Frechet, J. Am. Chem. Soc., 1991, 113, 4583.

9 J. F. Stumbé and B. Bruchmann, Macromol. Rapid Commun., 2004, 25, 921.
10 Z. Ge, S. Luo and S. Liu, J. Polym. Sci., Part A: Polym. Chem., 2006, 44, 1357.

11 G. Jayamurugan and N. Jayaraman, Tetrahedron, 2006, 62, 9582.

12 H. Arima, K. Motoyama and T. Higashi, Adv. Drug Delivery Rev., 2013, 65, 1204.

13 W. Wu, W. Driessen and X. Jiang, J. Am. Chem. Soc., 2014, 136, 3145.

14 L. Chonco, J. F. Bermejo-Martin, P. Ortega, D. Shcharbin, E. Pedziwiatr, B. Klajnert, F. J. de la Mata, R. Eritja, R. Gómez, M. Bryszewska and M. A. Mũnoz-Fernandez, Org. Biomol. Chem., 2007, 5, 1886.

15 N. Larson and H. Ghandehari, Chem. Mater., 2012, 24, 840. 16 Z. Li and Y. Chau, Bioconjugate Chem., 2009, 20, 780.

17 A. Lakshminarayanan, V. Kumar Ravi, R. Tatineni, Y. B. R. D. Rajesh, V. Maingi, K. S. Vasu, N. Madhusudhan, P. K. Maiti, A. K. Sood, S. Das and N. Jayaraman, Bioconjugate Chem., 2013, 24, 1612.

18 S. D. Bergman and F. Wudl, J. Mater. Chem., 2008, 18, 41.

19 A. Muzaferov and E. Rebrov, Chapter 2: Polysiloxane and Siloxane-Based Dendrimers, in Advances in Silicon Science Volume 2, Silicon-Containing Dendritic Polymers, ed. J. Matisons, Springer, 2009.

20 B. He, S. Rhodes-Brower, M. R. Miller, A. E. Munson, D. R. Germolec, V. R. Walker, K. S. Korach and B. J. Meade, Toxicol. Appl. Pharmacol., 2003, 192, 254.

21 D. H. Guimares, M. de Meireles Brioude, R. Da Paz Fuiza, L. A. Sanchez de Almeida Prado, J. S. Boaventura and N. M. Jose, Mater. Res., 2007, 10, 257.

22 Y. Yang, W. Lu, J. Cai, Y. Hou, S. Ouyang, W. Xie and R. A. Gross, Macromolecules, 2011, 44, 1977.

23 S. Skaria, M. Smet and H. Frey, Macromol. Rapid Commun., 2002, 23, 292.

24 Y. Z. Zhang, S. Spinella, W. Xie, J. Cai, Y. Yang, Y. Z. Wang and R. A. Gross, Eur. Polym. J., 2013, 49, 793.

25 M. A. Brook, Silicon in Organic, Organometallic, and Polymer Chemistry, Wiley, New York, NY, USA, 2000.

26 M. J. Owen, Siloxane Surface Activity, in Silicon-Based Polymer Science, A Comprehensive Resource, ed. J. M. Zeigler and F. W. G. Feardon, American Chemical Society, Washington, D. C., USA, 1990.

27 J. W. White and R. C. Treadgold, Organofucntional Siloxanes, in Siloxane Polymers, ed. S. J. Clarson and J. A. Semlyen, Prentice Hall, Englewood Cliffs, New Jersey, USA, 1993.

28 D. R. Thomas, Cross-Linking of Polydimethylsiloxanes, in Siloxane Polymers, ed. S. J. Clarson and J. A. Semlyen, Prentice Hall, Englewood Cliffs, New Jersey, USA, 1993.

29 M. Jang and J. V. Crivello, J. Polym. Sci., Part A: Polym. Chem., 2003, 41, 3056.

30 A. Saxena, S. Rajaraman and M. Leatherman, Macromolecules, 2007, 40, 752.

31 J. B. Grande, D. B. Thompson, F. Gonzaga and M. A. Brook, Chem. Commun., 2010, 46, 4988.

32 J. B. Grande, F. Gonzaga and M. A. Brook, Dalton Trans., 2010, 9369. 
33 M. A. Brook, J. B. Grande and F. Ganachaud, Adv. Polym. Sci., 2011, 235, 161.

34 L. Guo, Z. Zhang, Y. Zhu, J. Li and Z. Xie, J. Appl. Polym. Sci., 2008, 108, 1901.

35 R. Mosurkal, L. A. Samuelson, V. S. Parmar, J. Kumar and A. C. Watterson, Macromolecules, 2007, 40, 7742.

36 B. Sharma, A. Azim, H. Azim, R. A. Gross, E. Zini, M. L. Focarete and M. Scandola, Macromolecules, 2007, 40, 7919.

37 Y. Poojari, A. Palsule, M. Cai, S. J. Clarson and R. A. Gross, Eur. Polym. J., 2008, 44, 4139.

38 Y. Poojari and S. J. Clarson, Macromolecules, 2010, 43, 4616. 39 Y. Poojari and S. J. Clarson, Chem. Commun., 2009, 6834.

40 Y. Poojari and S. J. Clarson, Silicon, 2009, 1, 165.

41 Y. Poojari and S. J. Clarson, J. Inorg. Organomet. Polym., 2010, 20, 46.

42 M. B. Frampton, I. Subczynska and P. M. Zelisko, Biomacromolecules, 2010, 11, 1818.

43 M. B. Frampton, J. Séguin, D. Marquardt, T. A. Harroun and P. M. Zelisko, J. Mol. Catal. B: Enzym., 2013, 85-86, 149.
44 M. B. Frampton and P. M. Zelisko, Enzyme Microb. Technol., 2014, 58-59, 87.

45 M. B. Frampton and P. M. Zelisko, Chem. Commun., 2013, 49, 9269.

46 R. Panisch, A. R. Bassindale, A. A. Korlyukov, M. B. Pitak, S. J. Coles and P. G. Taylor, Organometallics, 2013, 32, 1732.

47 Y. A. Pozdnyakova, A. A. Korlyukov, E. G. Kononova, K. A. Lyssenko, A. S. Peregudov and O. I. Shchegolikhina, Inorg. Chem., 2010, 49, 572.

48 N. Ihara, M. Kurisawa, J. E. Chung, H. Uyama and S. Kobayashi, Appl. Microbiol. Biotechnol., 2005, 66, 430.

49 R. Ito, Y. Kakihana and Y. Kawakami, Chem. Lett., 2009, 38, 364.

50 J. Pleiss, M. Fischer and R. D. Schmid, Chem. Phys. Lipids, 1998, 93, 67.

51 H. C. M. Byrd and C. N. McEwen, Anal. Chem., 2000, 72, 4568. 52 A. M. Belu, J. M. DeSimone, R. W. Linton, G. W. Lange and R. M. J. Friedman, J. Am. Soc. Mass Spectrom., 1996, 7, 11.

53 M. Schömer and H. Frey, Macromol. Chem. Phys., 2011, 212, 2478. 